\title{
Gastric Cancer pN3 TNM Finding v6
}

National Cancer Institute

\section{Source}

National Cancer Institute. Gastric Cancer pN3 TNM Finding v6. NCI Thesaurus. Code C61195.

Gastric cancer with evidence of metastasis in more than 15 regional lymph nodes. (from AJCC 6th Ed.) 